\title{
イエバエ成虫の駆除効果判定法に関する一考察
}

\section{Some observations on the evaluating methods of house fly population}

\author{
平 社 俊之 助* \\ Shunnosuke Hirakoso
}

各種の殺虫剤の効力を知るために泣，室内的な実験を 行つても, ある程度の優劣注推測出来るが, 究極には, やはり, 実際の野外において, その特徽, 使用法という ものを検討する必要がある。

イエバエなどの野外実験を行う場合，常に問題々なる 点は，その効果の判定法である。

我が国に㧍いても，大利ら（1959）が，詳細に，この 判定法について検討している。この結果では，フライグ リル，八エとりリボン。八エとり紙の間では，大方の平 行的関係が認められている。 また鈴木ら (1959) は, malathion によるイエバェの駆除実験の中で, ハエとり リボンと八エとり瓶の間に, 薬剤散布, 無散布地区共, 有意な相関々係が示された上結論している，な抢，その 時の観察によると，天候，気温による変化は特に有意差 がみられなかつたと報告している。

これに反し，藤戸ら（1956）汢八エとりリボンと八エ とり瓶では, 前者が malathion 散布によつて無散布地区 と明らかに異る結果を得たのに反し，後者はこの差が 有意でないことからこの二つの判定法の間には必ずし も関連性がないのではないかと述べている.

しかし，これらの結果汶，いずれも実際の野外で行わ れたものであり，しかも各判定法によつて観察された八 エの増減上いう大きな規準で検討したものである.

従つて，その増減の程度の間に各判定法が，どの程度 影響し合つているかについては追究されていない. 更に 重要なことは，これらの結果が、いずれも，そこにいた 絶対八土数（総八工数）をつかんでいないため,どの方 法がより正確にそこにいる八エの数をつかんでいるかに ついては検討されていないことである。

* 東京大学伝染病研究所寄生虫研究部（部長：佐々学 教授)

Department of Parasitology, Institute for Infectious Diseases, University of Tokyo (Chief: Prof. Manabu Sasa)

中央化学株式会社, Chuo Kagaku Co., LTD.
しかしこの点を追究するとな机ばどうしても，む， らかじめ正確に数を算えたイエバェを一定の場所に放 ち,このもとで実験を行う必要があり，野外の自然に発生。 した八エを対象として行うことは事実上不可能である。

この意味から、ここに行つた実験は、飼育繁殖したイ エバエ成虫を用い，室内的及び淮野外的な実験を行つた。 ものである。

\section{供 試 虫}

イエバエ Vusca vicina Macquart 成虫: 本供試虫は: 平社(1958)に報告したものと同じ系統及び飼育方法で, 当研究室において累代飼育中のものである.なお, 羽化 後の経過日数等は, 各々文中に説明を加えたが, 特に示 していない場合は, 羽化 3 日〜 5 日後のものである.

\section{供 試 実験}

ここに述べる実験において，準野外実験に用いた二つ の室は次の通りである。

飼育室 $(\mathrm{S})$ 一床面はコンクリートで $2.4 \times 3.15 \mathrm{~m}$ の面 積であり, 床より天井までの高さは $2.0 \mathrm{~m}$, 室の四方は 約 $55 \mathrm{~cm}$ 幅の寸のこ状の棚に囲まれており，この棚は一 部を除いて全て，3段になつており，1段目は床より $65 \mathrm{~cm} ， 2$ 段目は $110 \mathrm{~cm} ， 3$ 段目は $157 \mathrm{~cm}$ の高さに各々 設置されている。この室は床を除き各面は淡緑色の塗料

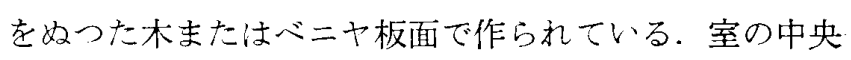
の天井に 40W の螢光燈が付けられてあり,この室のや や中央空奇り (北側) に, $50 \mathrm{~cm} \times 100 \mathrm{~cm}$, 高さ $95 \mathrm{~cm} の$. テーブルが置かれている. 室の温度は常に $25^{\circ} \mathrm{C}$ に調節 されている. (図1参照)

室 $(\mathrm{H})$ 一床はやはりコンクリートで作られ，3.0×4.7 $\mathrm{m}$ の面積, 高さは $2.0 \mathrm{~m}$, 床以外注, 素面のベニヤ板で 作られている. 北側に空があり，この面に高さ $75 \mathrm{~cm} の$ テーブルが置かれている.

室の温度は, 特に人工的に調節されてなく自然の条件 のままになつている所である（図2 参照) 


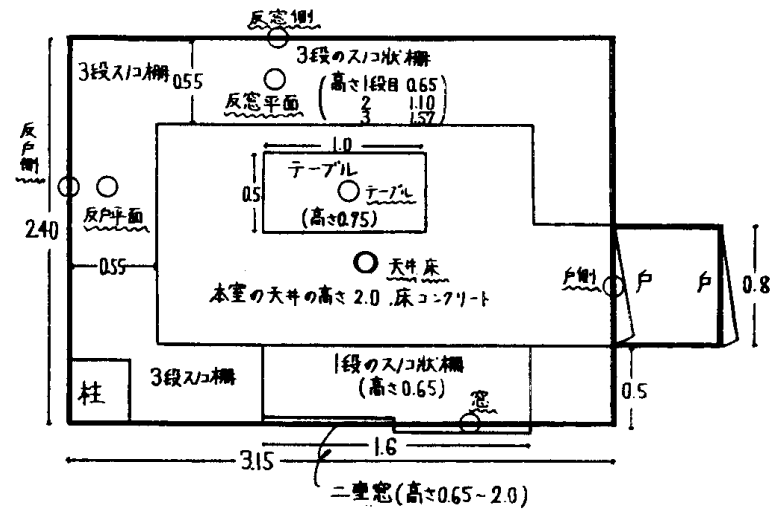

図 1 飼育室 $(\mathrm{S})$ の略図（長さの単位はメートル）

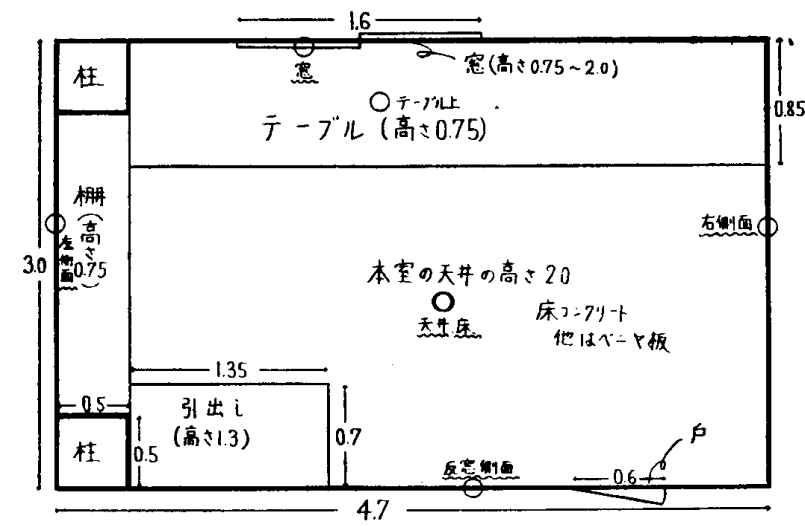

図 2 室 $(\mathrm{H})$ の略図（長さの単位はメートル）

実唤 1.フライタリル指数とハエとり紙捕獾イエバエ 数の関係：今日，最も普通に行われている判定法の一つ としてフライグリルによる方法があげられるが，この方 法はかなり多くの八エがいるのにもかかわらず，これに 止まる八エの数注非常に少く，八エの密度が少なる場 合, 実験が行いにくい。

このため，まず，フライグリルとハエとり紙による八 エの係留または捕獲数の関係を検討してみた.

図 3 は $25^{\circ} \mathrm{C}$ の飼育室 $(\mathrm{S})$ に異なる八工数を放し，そ の時のフライグリルによる八エ指数と八エとり紙に捕獲 された八エ数の関係を図示したものである.

フライグリルは $45 \mathrm{~cm}$ 角のものを用い，30 秒間放置 した後の最初の 1 回の観察数を，八エとり紙は $25 \times 36$ $\mathrm{cm}$ のものを使用し， 5 分間以内に，そこに係留捕獲さ れたイエバエ数を求めたものである。これらを置いた場 所は，床面中央近くで，特に八エが多く集まつていた所 である。

この結果では，フライグリルは，やはり，しゆんかん 的に，そこに止つている数をみているため，その数は少 く，八エとり紙は，これより，かなり多くの八エが観察 されている.

そして，八エとり紙に捕獲された八工数と放逐した八 工数との関係汇ついて，グラフを求めると，ほぼ一定の
傾向を持つた曲線が求められる。これに対し，フライグ リルの方は，一見したところ，かなり観察点が乱れてい る.そして，この両者を同じ単位で比較検討するため， 両者の最高係留八工数を 100 とした時の放逐八工数の関 係を求めた。

図 3 は，その結果である.この図をみると，フライグ リルの指数は，その八工数が少いため，その結果が乱机 ている様であるが，本質的には両者共，大差のないもの であると考える。

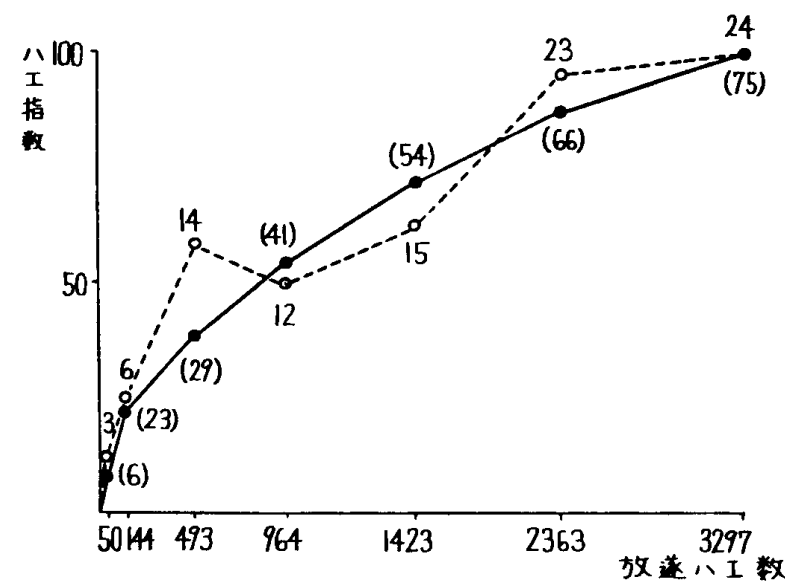

図 3 フライグリルとハェトリ綎 5 分間設置に よる係留観察ハェ数の比較，実験温度 $25^{\circ} \mathrm{C}$ (飼育室 $\mathrm{S}$ )

このことから，以下の塞験では，主に八エとり紙を用 いて実験を行つた。

この結果で注目されることは，放逐イエバエ数の増加 と観察イエバエ数の間に，直線的な比例関倸がみられな いことである.

このことは，観察八エ数が倍に増大しても，そこにい る八エ数が倍になつたという仮定が成り立たないことを 示している.

この様な現像が，なぜ起るかについては，明らかでは ないが，その一つとして考えられることは，フライグリ ル等を置いた場所が，八エの割合多く集まる場所であつ たため，そこにいる絶対八エ数が少い時は，この好適な 場所に，その多くが集つて来られるのに反し，だんだん 数が多くなるにつれ，その場所は，八土が適当とする状 態より多くのハエが集つてしまい，やむなく，第二の好 適な場所に移動するためと考えられる。

このため，放逐八工数の少い時汢，多くの八エが，そ の判定法で示され，放逐数の増大に伴つて，観察される 八エの割合が，全数に比較し少なくなるのではないかと 考える.

実験 2. 自然条件において，イエイエ成虫のハエとり 紙に捕獾される数の変動 : 1960 年 12 月から，1961 年の 
表 1 温度の違いによつてハェ取り紙に捕獲さ れるイェバェ成虫数の变動

\begin{tabular}{|c|c|c|c|c|c|c|}
\hline $\begin{array}{l}\text { 実験 } \\
\text { 温度 }\end{array}$ & 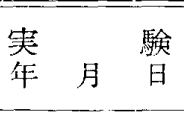 & $\begin{array}{c}\text { 照度 } \\
(\operatorname{Lux})\end{array}$ & $\mid \begin{array}{l}\text { 王の } \\
\text { 羽化後 } \\
\text { 日 }\end{array}$ & $\begin{array}{l}\text { 放逐 } \\
\text { 父 } \\
\text { 数 }\end{array}$ & $\left|\begin{array}{c}\text { 捕獲 } \\
\cdots \\
\text { 数 }\end{array}\right|$ & $\begin{array}{c}\text { 捕獲率 } \\
(\%)\end{array}$ \\
\hline $12^{\circ} \mathrm{C}$ & 1960.12 .26 & 210 & 4日後 & 1000 & 1 & 0.1 \\
\hline 12 & 1961.01 .28 & 250 & 4 & 4000 & 1 & 0.03 \\
\hline 13 & 1960.12 .26 & 250 & 4 & 4000 & 20 & 0.5 \\
\hline 13.5 & 1660.12 .24 & 295 & 4 & 2000 & 51 & 2.55 \\
\hline 15 & 1961.03 .02 & 295 & 7 & 2000 & 32 & 1.6 \\
\hline 15 & 1961.03 .11 & 320 & 4 & 2000 & 0 & 0 \\
\hline 15 & 1961.03 .11 & 320 & 4 & 2000 & 4 & 0.2 \\
\hline 15.5 & 1960.12 .24 & 480 & 4 & 1000 & 31 & 3.1 \\
\hline 16 & 1960.12 .20 & 350 & 4 & 4000 & 7 & 0.175 \\
\hline 18 & 1961.11 .09 & 500 & 4 & 2000 & 246 & 12.3 \\
\hline 19.2 & 1961.05 .20 & 1000 & 3 & 4000 & 602 & 15.05 \\
\hline 21 & 1961.04 .22 & 700 & 4 & 4030 & 831 & 20.775 \\
\hline 22 & 1961.05 .04 & 700 & 4 & 4000 & 614 & 15.35 \\
\hline 22 & 1961.05 .08 & 1150 & 4 & 2000 & 317 & 15.85 \\
\hline 22 & 1961.10 .14 & 200 & 4 & 2000 & 218 & 10.9 \\
\hline 23.4 & 1961.05 .10 & 300 & 4 & 1000 & 187 & 18.7 \\
\hline 24.4 & 1961.05 .16 & 850 & 4 & 2000 & 580 & 29.0 \\
\hline 26.5 & 1961.06 .08 & 600 & 3 & 4000 & 476 & 11.9 \\
\hline 26.8 & 1961.03 .27 & 540 & 4 & 4000 & 444 & 11.1 \\
\hline 29 & 1961.08 .08 & 600 & 4 & 2000 & 429 & 21.45 \\
\hline 31.5 & 1961.07 .31 & 800 & 4 & 2000 & 404 & 20.2 \\
\hline
\end{tabular}

11月に亘る，ほぼ 1 年間，室 $(\mathrm{H})$ に 1000 から 4000 匹の イエバェを適当な日に放ち，この室のテーブル上の一定 場所に八エとり紙 1 枚 $(35 \times 36 \mathrm{~cm})$ を置き，1 時間以内 に，これに捕獲された八工数の変動を求めた。

この室 $(\mathrm{H})$ は，特に冷暖房を加えず，自然の温度条件 のもとに置かれた室である.

表 1 が，その結果である。実験日，実験時の温度, 照 度, 供試虫の羽化経過日等は, 表中に示す通りである.

温度は室の中央空間にて測定, 照度は, 八エとり紙の 配置場所より，測定器を天井に向け測つた結果である. 供試イエバエは, 実験前, 約15分, 同室内に放置, ある 程度その温度条件に順态させた，全ての実験は，午後 2 時から 3 時をでの範囲内にて行つた。

この結果をみると, 主に温度の変化と, 捕獲八工数の 間に関連がみられる様である。

照度等も結果を変動させる要因になると思われるが， この様な実験では，これらの影響をつかむことは出来な かった。

図 4 は, 表 1 より, 温度と八エの捕獲率の関係を結ん だグラフである.

この図から判断すると， $15^{\circ} \sim 16^{\circ} \mathrm{C}$ 以下では，捕獲さ れるハエの数は非常に少く，18 $\mathrm{C}$ 以上になると急激に

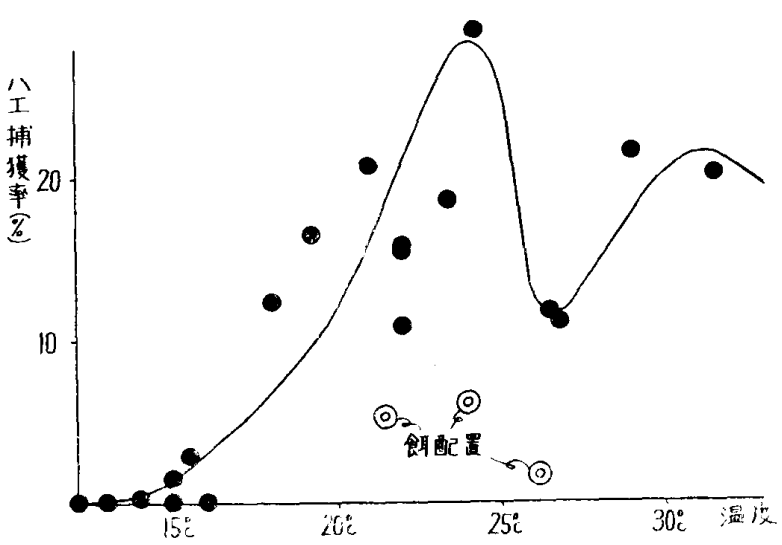

図 4 温度等の違いによつてテーブル上配置の ハェトリ紙に捕獲されるイエバェ成虫数 の変動 (室H)

その捕獲数が上昇し, $23^{\circ} \mathrm{C}$ から $25^{\circ} \mathrm{C}$ にて最高に達し

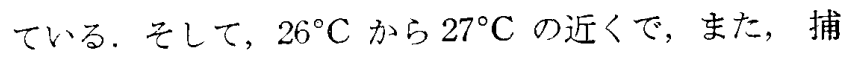
獲数がやや減少し，また $30^{\circ} \mathrm{C}$ 内外で上昇している.

また図中，「解配置」と記るされている点は，高さ2 $\mathrm{cm}$, 直径 $9 \mathrm{~cm}$ のシャーレ20個を，ほぼ等隔間に配置 し,この十に, 丁度満される程度の八エの慨を入れ，同 様の実験を行つた時の八エ成虫の捕獲率（\%）である.

用、た䬺は，動物飼育用粉末飼料 CE- 2 及びふすまを 等重量加え合せ，これに水を加え，权つたものであり， イエバエ飼育に用いられているものと同じものである。

この领の配置は明らかに，配置しないものより低い捕 獲率であることが認められる。

それでは，何故，この椂に八エの捕獲率が，いろいろ の環境によつて変つて来るかについて以下の実験を行つ た.

夷験 3. 温度の蓳いによるイエパ成虫の係留場所の 変化 : 実験 2 の結果に拈いて，一定数の八エが，室の内 にいるのにも拘らず，八土取り紙に捕獲される数が少な くなつて来ると言うことは次の原因が考えられる.

まず，その一つとして，八エが活動しないため，八工 とり紙の上に飛来して来ないこと，次に，活潑に活動は しているが，八エとり紙を設置したテーブル上に八エが 集まらず，他の場所に係留しているための二つが考えら れる。

ここに行つた実験は，温度と棲息八工数が異なる時， どの様な場所に多くの川エが係留するか在観察したもの である。

供試八エとしては，羽化4 日後の健全なものを用い， 実験室 $(\mathrm{H})$ を用い，100匹から6000匹の供試虫を放逐し 室内各面合せて 7 力所の観察場所を定め,ここに係留し ていたハエの数を記録したものである。

観察面はいずれも $40 \mathrm{~cm} \times 75 \mathrm{~cm}$ の長方形の面積で， その場所は次の通りである。 
（1）天井面一天井の中央部，（2）床面 1 室の床面( コ ンクリート）の丁度中央，（3）テーブル上一床より高さ $75 \mathrm{~cm}$ のテーブル上，（4）空側面一室の北側にあるガラ ス空の一部，床より $75 \mathrm{~cm}$ より $200 \mathrm{~cm}$ の高さのところ (5) 反空側面一空側面と丁度向い合つた南側のベニヤ板 の壁面，(6)，（7）左側面, 右側面一空側，反空側面以 外の残り 2 つのベニヤ板の側壁面である

観察は，各所定数の供試虫を放逐してなら，5分〜10 分経過し，ほぼ八エが落着きをみせた時，各観察面に止 つていた八エ数を 1 回数えた.

実験時の温度汢室中央にて，照度注各観察面中央部に 測定器を天井に向けたものと，観察面中央に直角に対す る位置で，かつ $30 \mathrm{~cm}$ 離れた場所より測定したものの両 者である。

表：放逐イエバェ成虫数を变えた時の係留場 所の变化 実験温度 $9^{\circ} \mathrm{C}$, 羽化 4 日後イ エバェ

\begin{tabular}{|c|c|c|c|c|c|c|c|}
\hline \multirow{2}{*}{$\begin{array}{l}\text { 放 逐 } \\
\text { 八工数 }\end{array}$} & \multicolumn{7}{|c|}{ 各観察面に止つていたハエ数 } \\
\hline & 天井 & 床 & $\begin{array}{l}\text { テーブ } \\
ル \quad \text { 上 }\end{array}$ & 空側 & $\begin{array}{c}\text { 反空 } \\
\text { 側 }\end{array}$ & 左側 & 右側 \\
\hline 100 & 1 & 0 & 0 & 0 & 1 & 1 & 0 \\
\hline 500 & 3 & 0 & 0 & 0 & 1 & 15 & 5 \\
\hline 1000 & 4 & 1 & 0 & 0 & 1 & 15 & 6 \\
\hline 2000 & 11 & 3 & 0 & 0 & 11 & 42 & 21 \\
\hline 3000 & 16 & 11 & 0 & 0 & 11 & 49 & 19 \\
\hline 4000 & 28 & 11 & 2 & 0 & 16 & 72 & 33 \\
\hline 5000 & 45 & 4 & 2 & 0 & 21 & 100 & 36 \\
\hline 6000 & 64 & 5 & 2 & 0 & 38 & 128 & 48 \\
\hline 照度 & 70 & 5 & 260 & 240 & 30 & 40 & 30 \\
\hline
\end{tabular}

表 3 放逐イエバェ成虫数を变えた時の係留場 所の变化 実験温度 $17.5^{\circ} \mathrm{C}$, 羽化 4 日 後イェバエ

\begin{tabular}{|c|c|c|c|c|c|c|c|}
\hline \multirow{2}{*}{$\begin{array}{l}\text { 放 逐 } \\
\text { 八 数 }\end{array}$} & \multicolumn{7}{|c|}{ 各観察面に止つていたハエ数 } \\
\hline & 天井 & 枺 & $\left|\begin{array}{rrr|}テ & -7 ゙ \\
ル & & 1\end{array}\right|$ & 空側 & $\begin{array}{c}\text { 反空 } \\
\text { 側 }\end{array}$ & 左側 & 右側 \\
\hline 100 & 0 & 0 & 5 & 0 & 1 & 0 & 0 \\
\hline 500 & 5 & 1 & 13 & 1 & 4 & 1 & 1 \\
\hline 1000 & 14 & 2 & 22 & 1 & 9 & 7 & 6 \\
\hline 2000 & 28 & 2 & 35 & 2 & 15 & 13 & 22 \\
\hline 3000 & 44 & 5 & 57 & 3 & 14 & 29 & 36 \\
\hline 4000 & 58 & 5 & 109 & 2 & 16 & 29 & 34 \\
\hline 5000 & 67 & 7 & 131 & 3 & 22 & 42 & 38 \\
\hline 6000 & 70 & 12 & 183 & 2 & 28 & 44 & 39 \\
\hline 照度 (天) & & 180 & 440 & 600 & 32 & 44 & 74 \\
\hline "I（直） & 40 & 14 & 70 & 1700 & 60 & 22 & 32 \\
\hline
\end{tabular}

$9^{\circ} \mathrm{C}$ において行つた結果は表 2 に $17.5^{\circ} \mathrm{C}$ の結果は 表 3 に, $26.8^{\circ} \mathrm{C}$ は表 4 に示した.

表 4 放逐イエバェ成虫数を变えた時の係留場 所の変化 実験温度 $26.8^{\circ} \mathrm{C}$, 羽化 4 日 後イェバエ

\begin{tabular}{|c|c|c|c|c|c|c|c|}
\hline \multirow{2}{*}{$\begin{array}{l}\text { 放 逐 } \\
\text { 八 数 }\end{array}$} & \multicolumn{7}{|c|}{ 各観察面に止つていたハェ数 } \\
\hline & 天井 & 床 & $\begin{array}{l}テ ー フ \\
ル \quad \text { 上 }\end{array}$ & 空側 & $\begin{array}{c}\text { 反空 } \\
\text { 側 }\end{array}$ & 左側 & 右側 \\
\hline 100 & 2 & 0 & 0 & 0 & 0 & 1 & 0 \\
\hline 500 & 4 & 6 & 3 & 2 & 1 & 2 & 1 \\
\hline 1000 & 6 & 14 & 8 & 0 & 2 & 2 & 3 \\
\hline 2000 & 15 & 30 & 13 & 2 & 2 & 4 & 4 \\
\hline 3000 & 19 & 52 & 38 & 1 & 1 & 6 & 2 \\
\hline 4000 & 27 & 67 & 53 & 0 & 2 & 8 & 1 \\
\hline 照度（天） & & 94 & 540 & 600 & 8 & 38 & 10 \\
\hline "I (直) & 14 & 4 & 80 & 1200 & 8 & 12 & 5 \\
\hline
\end{tabular}

これらの表よりすると, 温度が $6^{\circ} \mathrm{C}$ の時は, 左側面, 右側面及び天井面に多数の八エが係留している，上ころ が，18ㄷでは，テーブルの上に最も多くハエが集まり， 次いで天井面の順になつている. 更に $27^{\circ} \mathrm{C}$ では，床面 にいるハェが一番多く, 次いでテーブル上, 天井の順に なつて来る。

これらの三つの結果を組合せて考えると，温度が低い 場合は，概して，イエバエは，天井とか側壁面，すなわ ち室の隅に多く係留し，温度が上昇するにつれ，室の中 央, すなわち，テーブルの上などに飛来する様になり， 更に最適温度の近辺では, 室の中央でかつ林面の近くで 多く活動すると言う性質がみられる様である.

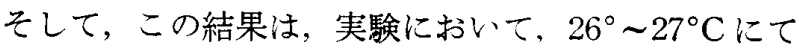
テーブル上に置いた八エとり紙に捕獲される八エ数が, $23^{\circ} \sim 24^{\circ} \mathrm{C}$ よ少なくなつていることを暗にうらゔけて いると思われる。

何故ならば， $27^{\circ} \mathrm{C}$ 内外では，多くの八エが，テーブ ル上よりむしろ，床面の方に多く集まつてしまうため， その捕獲数が少なくなつて来ると考えられるからであ る。

しかし，実験 2 では，更に $30^{\circ} \mathrm{C}$ 近くになると，また その捕獲数が上昇しているが，この原因については，ま た不明な点が多い.

次に放逐したイエバエの数と，各観察面に係留してい た八工数の関倸であるが，一般的には，放逐八工数の増 大に伴つて, 観察八工数も増加する傾向は明らかに認め られたが，その割合は，かならずしも放逐数の増大と比 例しているとは考えられない様である.

図 5 , 図 6 , 図 7 洛々, 表 2 , 表 3 , 表 4 の結果上 


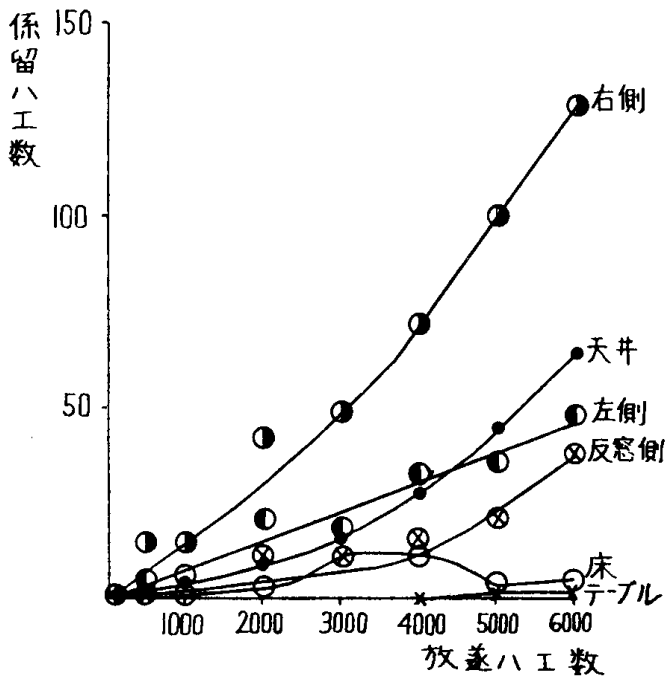

図 5 放逐イエバェ数を变えた時の各観察面上 に係留していたハェ成虫数の变動, 実験 温度 $9^{\circ} \mathrm{C}$

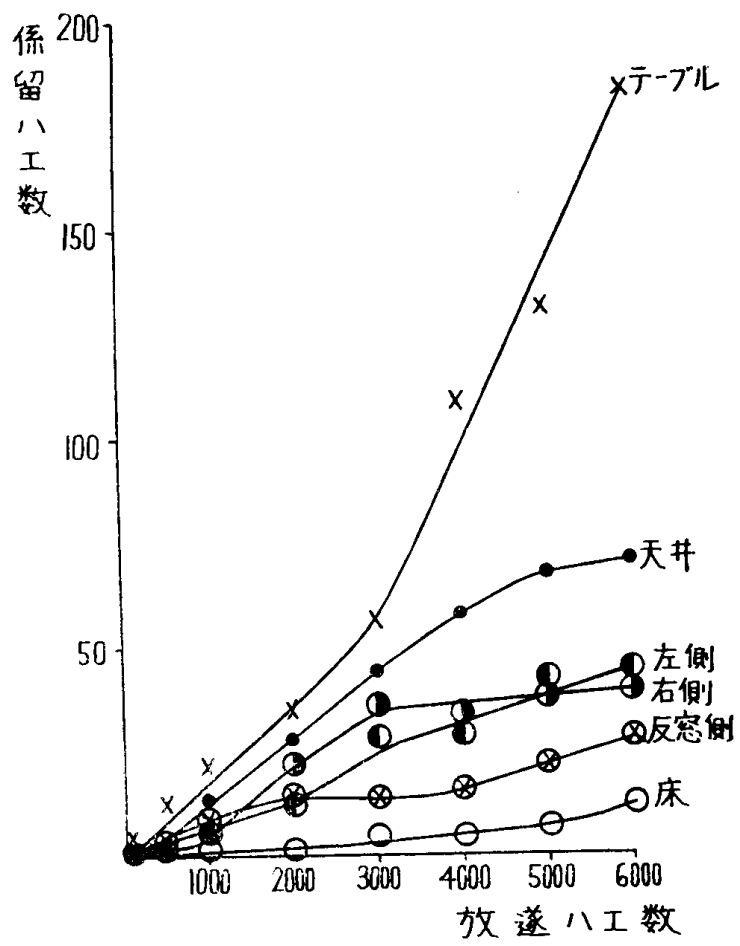

四 6 放逐イエバェ数を变えた時の各観察面上 に你留していたハェ成虫数の变動，実験 温度 $17.5^{\circ} \mathrm{C}$

り，縌軸に観察倸留八工数，横軸に放逐八工数をとりそ の両点を結んで曲線を求めた図である。

このグラフで分かる様に，多くの観察面の結果が，直 線ではなく，曲線になる様で，しかも，この結果が，放 逐八工数が増大した時に急激に観察八工数が増加するも のと、この逆のものとがみられる。

このことは，もし，ある一面のみしか観察しない場合 ある時 100 匹，八エが観察され，次の時に50匹観察さ

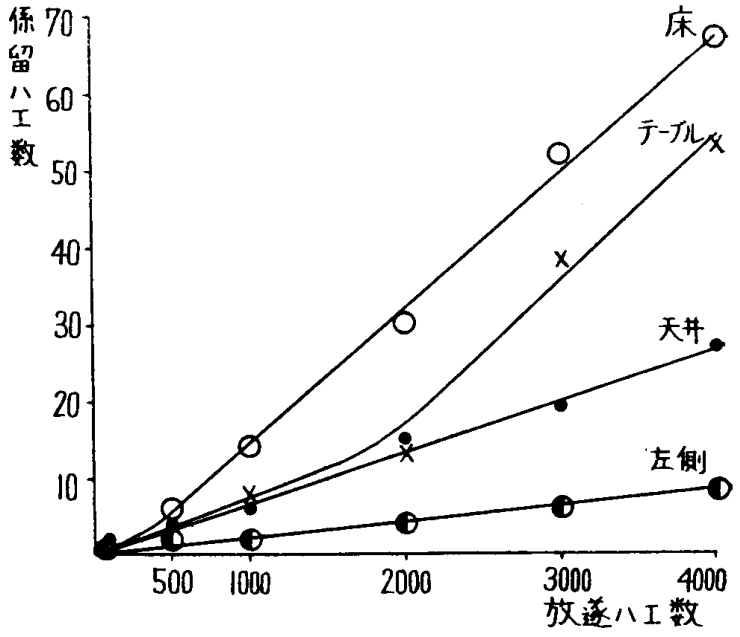

网 7 放逐イエバェ成虫数を变えた時の，各観 察面上に係留していたハェ数の变動，実 験温度 $26.8^{\circ} \mathrm{C}$

れたとし，しかも，その室の条件に全く変化がなかつた と仮定しても，そこにいる八エ全数が半分になつたと結 論することは間違いであるといらことになる。

尚，この結果は，先に述べた．フライグリル，八エと り紙の結果でも示されている.

次に各観察面，各↔について温度差の影響を考察して みたいと思う。

図 8，9，10，11は図 5，6，7のグラフから，ある 一つの観察面のみぬき出して, 各温度のものと比較, 図 示したものである。

まず，8図の天井面の結果文ると， $18^{\circ} \mathrm{C}$ の場合が 一番多く八エが観察され，次いで， $27^{\circ} \mathrm{C}, 9^{\circ} \mathrm{C}$ が，ほ ぼ同じ程度である。しかし、、ずれも，それほど多くの 違いがみられない様である。四 9 のテーブル上では， $18^{\circ} \mathrm{C}$ において最も多人八エが観察され，次いで， $27^{\circ} \mathrm{C}$ $9^{\circ} \mathrm{C}$ では，ほ上んど八エが係留しない様である。

闵 10 の床面の場合は, $27^{\circ} \mathrm{C}$ が一番多く, $18^{\circ} \mathrm{C}$ 以下 では観察されたハエの数は非常に少なくなつている。困

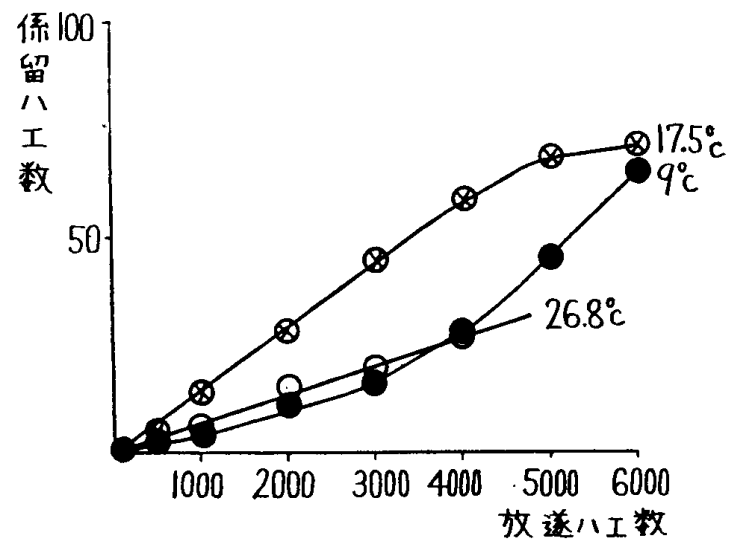

図 8 放逐イエバェ成虫数及び温度が变つた時 の天井面に係留観察された数 


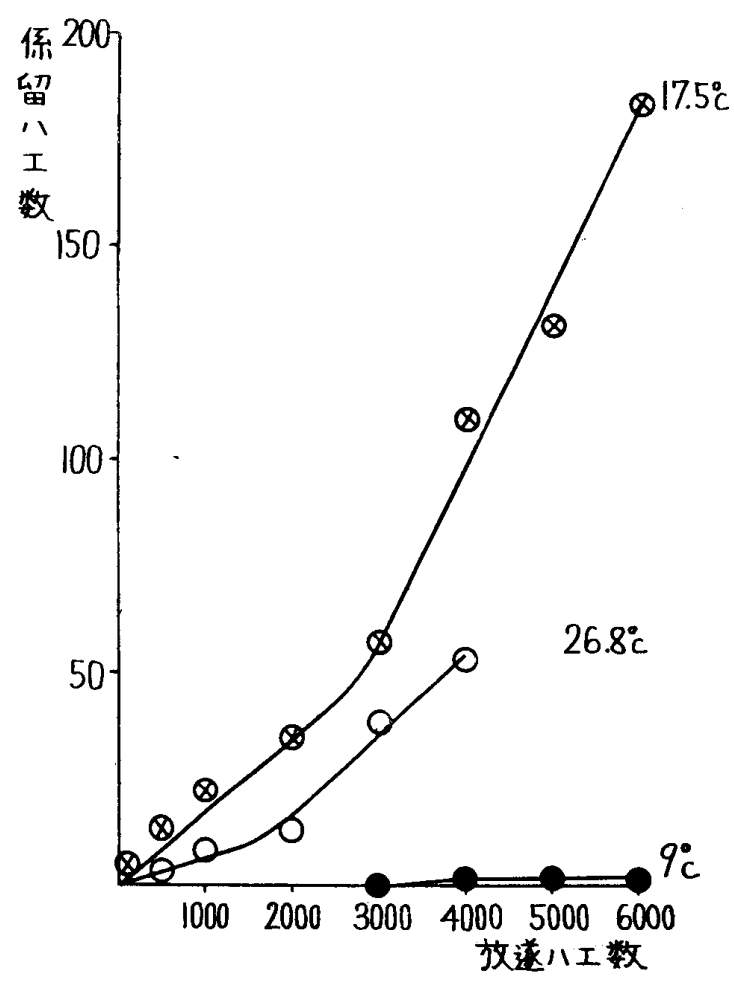

図 9 放逐イェバェ成虫数及び温度が変つた時 のテーブル上に係留観察された数

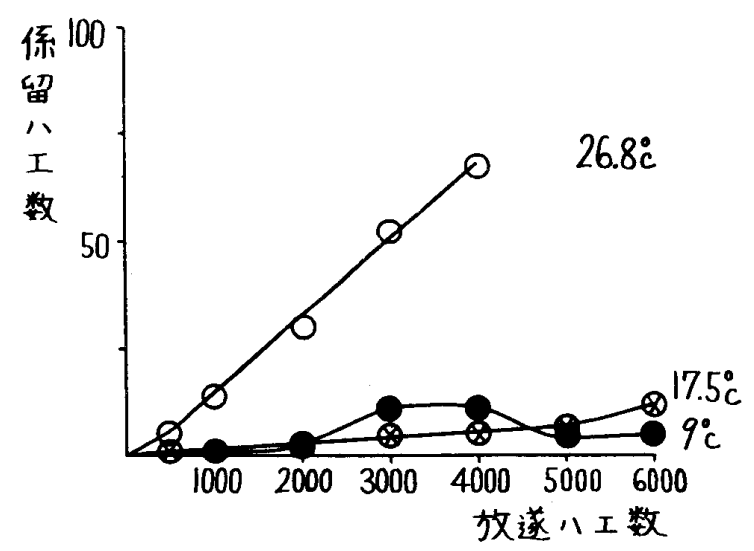

図 10 放逐イエバェ成虫数及び温度が变つた時 の床面に係留観察された数

11の側面では，温度の低い方が，多くのハエが観察され ている.

少くとも，この実験のみから推論すれば，床面は温度 の上昇と共に，そこに止まる八エの数は増加し，逆に側 面は温度の増大と共に，八エの数は減少すると云ら結果 になる，天井面は，いずれの温度でも，大差がないこと になる。

この結果も，供試した室の条件，供試虫，放逐した時 の方法等, 数多くの問題点があり, 必ずしも実際の野外 において，例外なく，この様な傾向を示すとは考えられ ない。しかし，少なくとも次のことだけは結論しても差 支えないと思う。すなわち，イエバエの成虫は，温度等

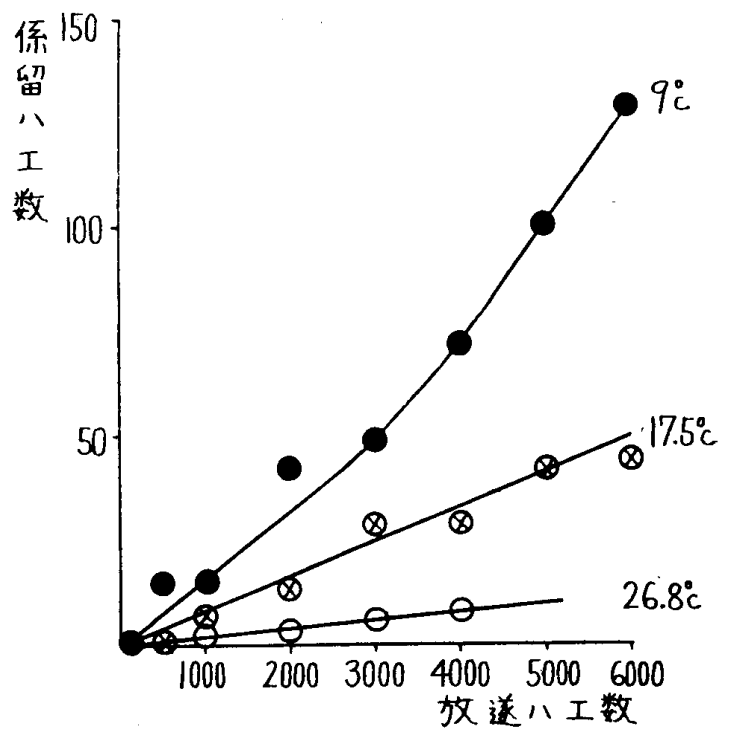

図 11 放逐イエバエ成虫数及び温度が変つた時 の左側面に係留観察された数

の変化によつて，その係留する場所が著しく異なり，あ る一面のみで観察された八工数をもつて，その室，全体 の八工数を，そのまま推定した場合，ある時は，そこに いる八エが実際には多くなつているにも拘らず，観察結 果では，少なくなつていると考える可能性が充分あると いうことである。

この項に扱つた実験の供試虫は，いずれむ羽化 4 日後 のものを使用したが，次に，やはり，同じ様な実験方法 を用いて，羽化後の経過日数の異なるイエバエを使つて 行つた結果について述べることにする。

実験 4. 羽化経過日数の異るイエパエ成虫の放逐数を 変えた時の係留场所の変化: 奏験は $25^{\circ} \mathrm{C} に$ 保たれた飼 育室 $(\mathrm{S})$ において行つた。供試したイエバエは羽化 1 日 後，3日後，8日後のものである.

イエバエ 成虫の 室内放逐方法は, 実験 3 と同様であ る.

観察した各面は，いずれも $40 \mathrm{~cm} \times 75 \mathrm{~cm}$ の長方形の 面積で，その観察場所は，(1) 天井面一中央やや空寄り の天井，（2）床面一天井面の丁度真下の床，（3）テーブ ルーテーブル上の中央, (4) 空一北側にあるガラス空面 で休よりその中心が約 $1.5 \mathrm{~m}$ の場所，(5) 戸側面一空に 向つて左の側面にあるドアーの一部，（6）反空側一空と 反対側の側面で床より $110 \mathrm{~cm}$ の所にある 2 段目の棚上 $157 \mathrm{~cm}$ の所にある 3 段目の棚の間，（7）反空平面一(6) の所の 2 段目の棚上の水平面上（8）反戸側面一戸側面 の反対側で，かつ，2 段目と3 段目の棚の間の側面,

(9) 反戸平面一－(8) の所の 2 段目の棚上の水平面上であ る.

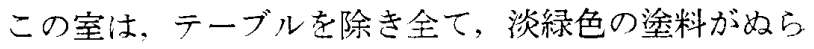


表 5 羽化後日数の異るイエバエ成虫の放逐数を变えた時の係留場所の变化

実験温度 $25^{\circ} \mathrm{C}$, 羽化 1 日後イエバェ

\begin{tabular}{|c|c|c|c|c|c|c|c|c|c|c|}
\hline 放逐 & & 観 & 察 & $k$ & & $D$ & $w$ & $\kappa$ & $\simeq$ & \\
\hline 八工 数 & 天 井 & 床 & $\begin{array}{l}\text { テ }- \text { ブ } \\
ル-\text { 上 }\end{array}$ & 葖 & 户 & 側 & 反 空 側 & 反空平面 & 反戸 側 & 反户平面 \\
\hline 100 & 4 & 2 & 3 & 0 & & 0 & 0 & 0 & 0 & 1 \\
\hline 500 & 6 & 2 & 7 & 0 & & 3 & 0 & 2 & 0 & 3 \\
\hline 1000 & 7 & 3 & 8 & 2 & & 4 & 0 & 8 & 1 & 7 \\
\hline 2000 & 12 & 5 & 25 & 2 & & 3 & 0 & 11 & 1 & 12 \\
\hline 3000 & 22 & 6 & 24 & 6 & & 4 & 0 & 15 & 2 & 10 \\
\hline 4000 & 41 & 10 & 47 & 7 & & 7 & 0 & 14 & 4 & 12 \\
\hline 5000 & 46 & 13 & 47 & 11 & & 13 & 0 & 18 & 4 & 20 \\
\hline 6000 & 67 & 17 & 50 & 10 & & 9 & 0 & 23 & 5 & 20 \\
\hline 7000 & 80 & 32 & 63 & 17 & & 13 & 0 & 34 & 3 & 19 \\
\hline 8000 & 81 & 52 & 57 & 15 & & 22 & 0 & 19 & 2 & 22 \\
\hline 照度（天） & & 120 & 215 & 320 & & 60 & 65 & 80 & 7 & 12 \\
\hline " $($ 直) & 84 & 8 & 34 & 700 & & 19 & 34 & 33 & 4 & 4 \\
\hline
\end{tabular}

表 6 羽化後日数の異るイエバエ戊虫の放逐数を变えた時の係留場所の変化

実験温度 $25^{\circ} \mathrm{C}$, 羽化 3 日後イェバエ

\begin{tabular}{|c|c|c|c|c|c|c|c|c|c|c|}
\hline 放逐 & & 観 & 面 & $k$ & & b & $w$ & k & $x$ & 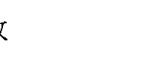 \\
\hline 八工 数 & 天 & 床 & $\begin{array}{l}\text { テ }- \text { ブ } \\
ル\end{array}$ & 空 & 戸 & 側 & 反 空 側 & 反空平面 & 反 戸 側 & 反戸平面 \\
\hline 100 & 0 & 0 & 1 & 0 & & 0 & 2 & 1 & 1 & 2 \\
\hline 500 & 5 & 3 & 9 & 0 & & 1 & 2 & 2 & 1 & 8 \\
\hline 1000 & 8 & 6 & 12 & 0 & & 2 & 0 & 12 & 3 & 10 \\
\hline 2000 & 11 & 4 & 22 & 0 & & 2 & 3 & 15 & 3 & 20 \\
\hline 3000 & 14 & 8 & 27 & 0 & & 6 & 3 & 14 & 4 & 21 \\
\hline 4000 & 16 & 16 & 32 & 0 & & 6 & 4 & 18 & 2 & 27 \\
\hline 5000 & 12 & 22 & 35 & 0 & & 8 & 0 & 25 & 3 & 33 \\
\hline 照度 (天) & & 85 & 200 & 198 & & 54 & 26 & 150 & 12 & 25 \\
\hline "I (值) & 410 & 6 & 44 & 400 & & 8 & 14 & 24 & 3 & 5 \\
\hline
\end{tabular}

表 7 羽化後日数の異るイエバエ成虫の放逐数を変えた時の係留場所の変化

実験温度 $25^{\circ} \mathrm{C}$, 羽化 8 日後イエバェ

\begin{tabular}{|c|c|c|c|c|c|c|c|c|c|c|}
\hline \multirow{2}{*}{$\begin{array}{l}\text { 放 逐 } \\
\text { 八工 数 } \\
\end{array}$} & \multicolumn{2}{|c|}{ 各 } & 面 & \multicolumn{2}{|c|}{ 止 } & $D$ & $\checkmark$ & th & \multicolumn{2}{|c|}{$x \quad$ 数 } \\
\hline & 天 井 & 床 & $\begin{array}{l}\text { テ }- \text { ブ } \\
ル\end{array}$ & 空 & 戸 & 側 & 反 空 側 & 反空平面 & 反 戸 側 & 反戸平面 \\
\hline 100 & 2 & 1 & 1 & 0 & & 0 & 0 & 1 & 0 & 2 \\
\hline 500 & 1 & 0 & 8 & 0 & & 3 & 0 & 3 & 0 & 7 \\
\hline 1000 & 2 & 4 & 12 & 0 & & 0 & 0 & 5 & 2 & 6 \\
\hline 2000 & 8 & 10 & 18 & 0 & & 5 & 0 & 9 & 2 & 14 \\
\hline 3000 & 1 & 21 & 30 & 0 & & 3 & 2 & 10 & 2 & 10 \\
\hline 4000 & 0 & 24 & 42 & 0 & & 3 & 0 & 5 & 2 & 14 \\
\hline 5000 & 5 & 22 & 43 & 0 & & 8 & 2 & 13 & 1 & 19 \\
\hline 照度（天） & & 72 & 240 & 160 & & 40 & 20 & 100 & 6 & 20 \\
\hline "I（直） & & 3 & 24 & 200 & & 8 & 8 & 16 & 2 & 4 \\
\hline
\end{tabular}


れている。

照度, 温度の測定は, 実験 3 に準じて行つた。

表 5 は羽化 1 日後の，表 6 は 3 日後，表 7 は 8 日後の イエバェ成虫を供試して行つた結果である。図 $12 ， 13$,

14，15，16は，表 5，6，7の結果より得られた值を，

各観察面毎に，羽化経過日数の異なる三つのイエバエの

放逐数と観察数の関係を図示したむのである.

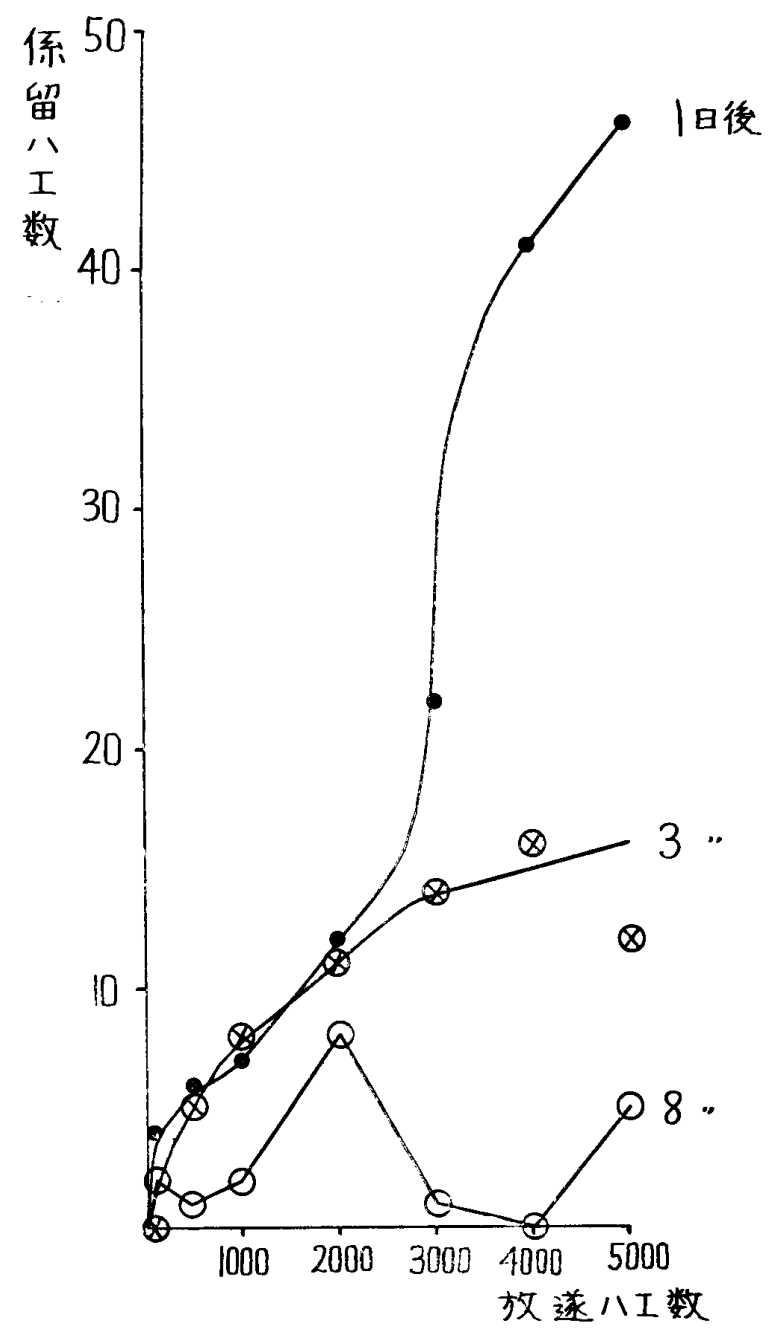

図 12 羽化経過日数の異なるイエバエ成虫の放 逐数を変えた場合，天井面に係留観察さ 机え八土数

これらのものからみると, 羽化 1 日後のイエバェは, 天井面に多く係留し，3日，8日後のものはテーブル上 により多く集つているが，大方の傾向では，羽化 1 日後 は，天井とテーブル上に多くのハエが集中しているのに 反し, 3 日後のものは, 各面にある程度, 分散している 様である. 羽化 8 日後は，テーブル上と床面に集中して いる.

各観察面, 個々について考えると, 天井面は, 羽化経 過日数の少いイエバェほど多く倸留し, その差も非常に 顕著である。

これに反して, 床面は羽化後の日数が多いものほど,

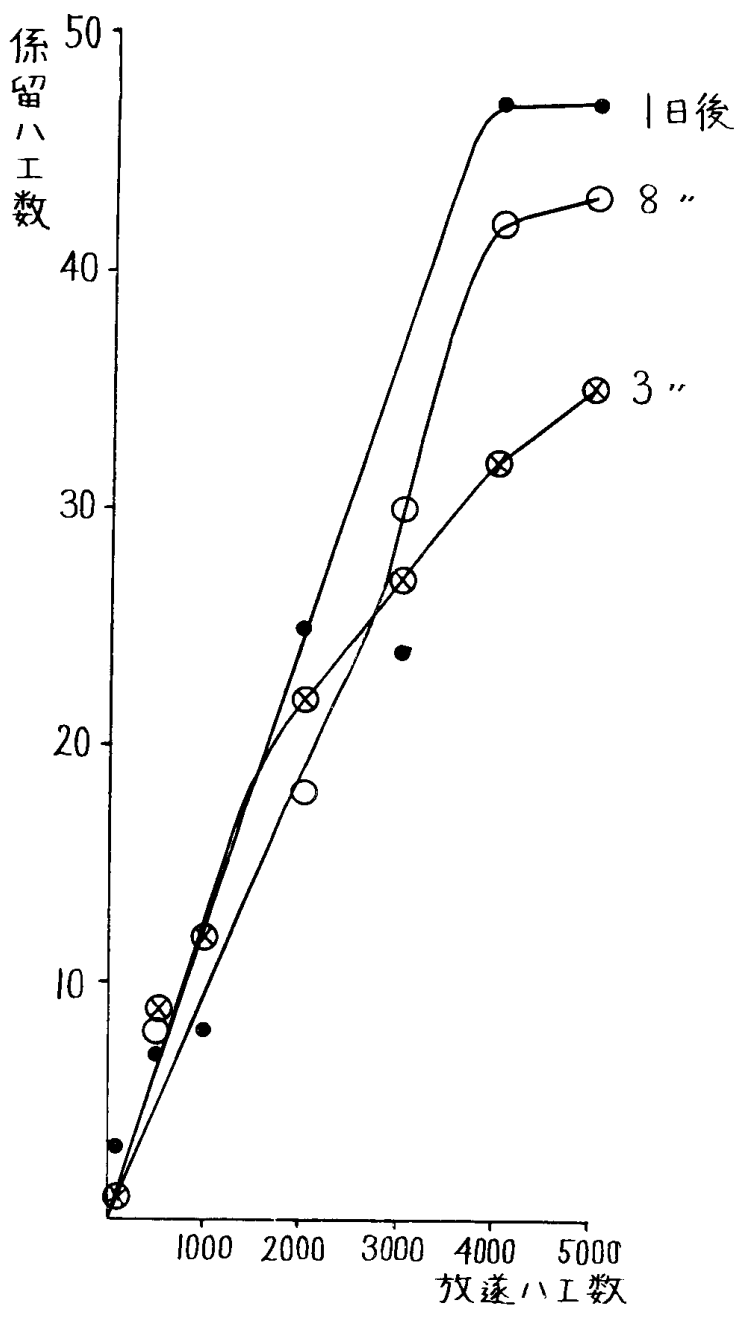

図 13 羽化経過日数の買なるイエバェ成虫の放 逐数を变えた場合，テーブル上に係留観 察されたハェ数

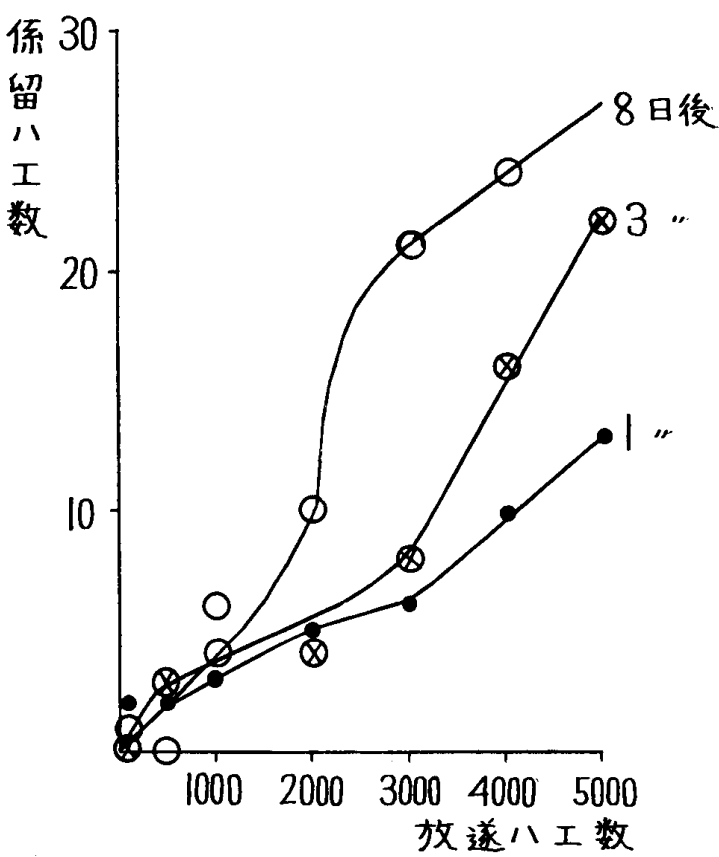

図 14 羽化経過日数の異なるイエバエ成虫の放 逐数を变えた場合，㦿面に係留観察され たハェ数 


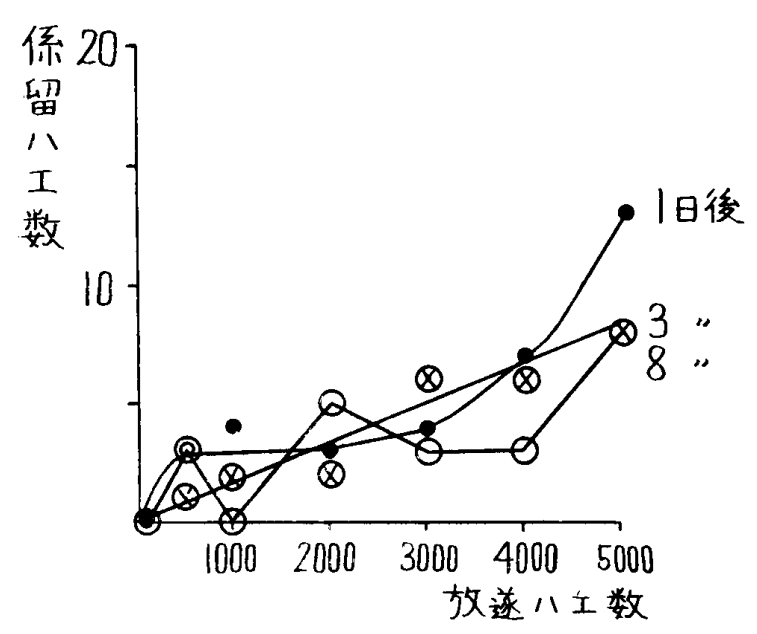

汉 15 羽化経過日数の異なるイエバェ成虫の放 逐数を变えれ場合，戸側面に係留観察さ れたハェ数

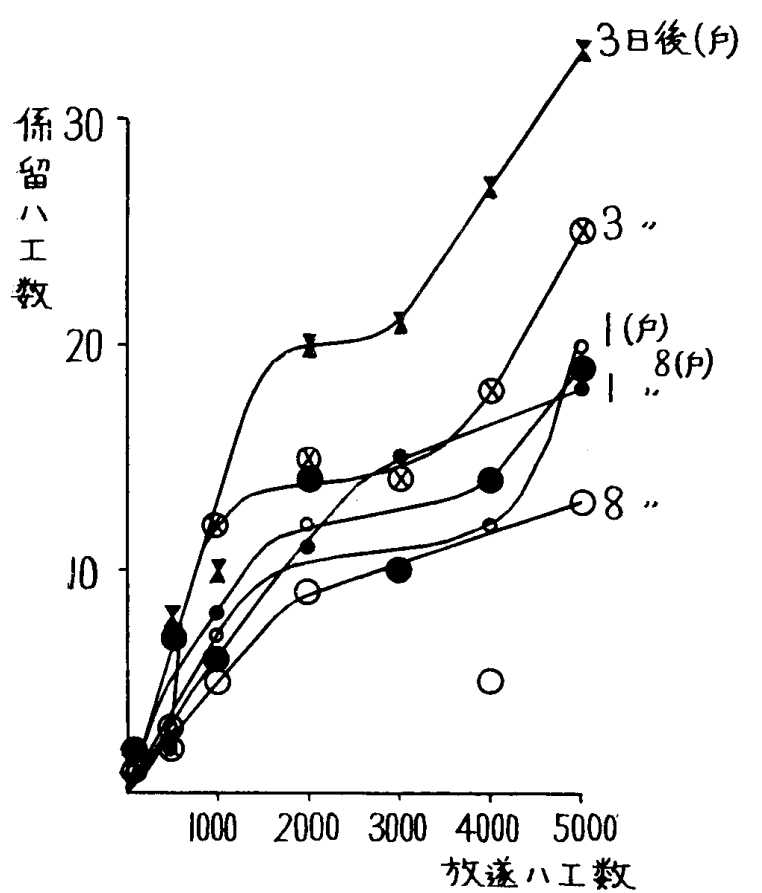

図 16 羽化経過日数の異なるイェバェ成虫の放 逐数を変えた場合，反空平面（図中特に 示していないもの), 反户平面(図中，力 ッコ内に戸と示した\&の) に係留観察さ れたハェ数

\section{よく集つて来る様である.}

テーブル上は実験 3 の温度による係留数の時と同じよ うに，一定した傾向がなく，1 日後と 8 日後が多く，3 日後は，これより，やや，係留八エ数が少なくなつてい る。

室の隅にある，水平面である，"反空平面"，“反戸平 面”の結果は，羽化 3 日後が一番多く，8 日後が一番低 い值になつている.

ここに行つた実験では，いずれもテーブル上にかなり
のハエが観察されているが，この原因として，室の中で このテーブルを除いて全部，塗装していること，このテ 一ブルの上で，いろいろの飼育上の慨などを取扱つてい たため，そこに，これが少し，しみついていたため，て こに八エが誘引されたと言うことも考えられる。

しかし，大方の結論を求めれば，羽化したばかりのイ エバェは，天井面に多く集まり，床面になると，古い八 エが多くなつて来る。そして中間的なテーブル上，ある いは，中間的な高さにある水平面では，かなり変動に富 んだ。中間的值を示す様である。

実䮦 5. 明るさの䢖いによるイエバエ成虫の活動性の 違い: フライグリルや八エより紙によつて，八エの棲息 数をみる場合，イエバエがもし，全く活動しないとすれ ば，いくら，そこに八エがいても，新たに，そこに設置 した，フライグリルやハエさり紙の上に，止つて来ると いらことは，あり得ないわけである。

そこで，このイエバエ成虫が，どの様な時に，より活 潑に活動するかについて実験を行つた。

まず，その一つとして，明るさの違いによる活動性を 調べた結果が，表 8 である。

供試虫イエバエは羽化 2 日後を用い，一辺が $30 \mathrm{~cm}$ の 正方形のハエケージの中に，300 匹の供試虫を放ち，そ のケージ底面中央に， $10 \mathrm{~cm} \times 10 \mathrm{~cm}$ の八エ上り紙を静か に入れ，全く静止の状態で，八エとり紙を入れてから， 1 分後, 2 分後, 5 分後及び 10 分後に, 各々, そこに 飛来捕獲された八エの数を記録した。実験した時の温度 は $25^{\circ} \mathrm{C}$ である。

表 8 をみると, 照度が250〜20lux の範用では，特に その活動性に違いはみられなかつた。しかし，かなり暗 くした時には，八エは活動しない様である。この結果で は，20〜4lux 以下では，急に八エが活動しない様に思 われ勝ちであるが，実際はこの間で徐々に活動しなく なつていくものと考えられる.しかし，こと活動性とい うことのみ考えれば，特に暗い場合を除き，それほよ゙影 響しない様である。

表 8 イェバェ成虫の活動性，明るさの違い

\begin{tabular}{|c|c|c|c|c|}
\hline \multirow{2}{*}{$\begin{array}{c}\text { 照 度 } \\
(\operatorname{Lux})\end{array}$} & \multicolumn{4}{|c|}{ 活動捕獲された平均イエバエ数 } \\
\hline & 1 分後 & 2 分後 & 5 分後 & 10分後 \\
\hline 250 & 7.7 & 13.3 & 16.7 & 26.3 \\
\hline $130 \sim 60$ & 8.5 & 11.5 & 19.5 & 27.0 \\
\hline $20 \sim 4$ & 8.0 & 11.0 & 18.5 & 24.5 \\
\hline 準 & 0 & 0 & 0 & 0 \\
\hline
\end{tabular}

註 準暗とは31lux 以下で，かつ，ゆっとハェが確 認出来る程度の明るさであるととを示す。 供試イエバェは羽化 2 日後 実験温度 $25^{\circ} \mathrm{C}$ 
実験 6. 1エバエ成虫の羽化経過日数および温度の䢖 いによる活動性の違い：この実験は，奏験 5 と同様の実 験方法を用い，供試イエバエ成虫として，羽化 1 日後と 8日後のものについて，3つの温度段階を用い行つたも のである。

結果は表 9 である.

表 9 イエバェ成虫の羽化経過日数及び温度の 違いによる活動性

\begin{tabular}{|c|c|c|c|c|c|c|}
\hline \multirow{2}{*}{$\begin{array}{l}\text { 供試 虫 } \\
\text { 羽 化 } \\
\text { 経過日数 }\end{array}$} & \multirow{2}{*}{$\begin{array}{l}\text { 奏験 } \\
\text { 温度 }\end{array}$} & \multirow{2}{*}{ 照度 } & \multicolumn{4}{|c|}{ 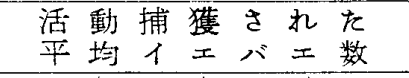 } \\
\hline & & & 1 分後 & 2 分後 & 5 分後 & 令10分後 \\
\hline 1 日後 & $17^{\circ} \mathrm{C}$ & 50lux & 0 & 0 & 0.5 & 0.5 \\
\hline $8 \prime \prime$ & $\prime \prime$ & $\prime \prime$ & 0.5 & 1.0 & 3.5 & 5.5 \\
\hline 1 & $18^{\circ} \mathrm{C}$ & 30 & 3.0 & 4.0 & 4.5 & 5.5 \\
\hline 8 & "I & "I & 0.5 & 2.0 & 8.0 & 20.0 \\
\hline 1 & $25^{\circ} \mathrm{C}$ & 20 & 2.5 & 5.0 & 21.0 & 36.0 \\
\hline 8 & $\prime \prime$ & 11 & 17.0 & 25.5 & 50.5 & 71.0 \\
\hline
\end{tabular}

この結果よりみると, 羽化 8 日後のイエバエは, 羽化 1日後のものより，はるかに活潑に活動する様である. また，温度も高いほど活潑になると考えられる。

表 10 は，八エとり紙の代りに，操作を簡単にするた め, 高さ $2 \mathrm{~cm}$, 直径 $9 \mathrm{~cm}$ のシャーレの中に, ほぼ一ぱ い，0.5\%中性洗剤水を入れたもの置き，10分後に， この液の中におぼれた八工数を, 各種の温度条件のもと で行つた結果である.

表 10 イエバエ成虫の温度差による活動性

\begin{tabular}{c|c}
\hline \hline 実験温度 & $\begin{array}{c}\text { 10分闑に活動捕獲さ } \\
\text { れた均イエハ数 }\end{array}$ \\
\hline $18^{\circ} \mathrm{C}$ & 8.0 \\
$21^{\circ} \mathrm{C} \sim 22^{\circ} \mathrm{C}$ & 30.5 \\
$24^{\circ} \mathrm{C}$ & 47.5 \\
$26^{\circ} \mathrm{C} \sim 28^{\circ} \mathrm{C}$ & 72.0 \\
$29^{\circ} \mathrm{C} \sim 30^{\circ} \mathrm{C}$ & 84.0 \\
$33^{\circ} \mathrm{C} \sim 34^{\circ} \mathrm{C}$ & 53.5
\end{tabular}

註 供試イエバエは羽化 9 日後

この実験は温度と八エの活動性をくわしく追究するた め, 明りは $40 \mathrm{~W}$ 螢光燈つを用い一定とし，八エケージ の設置場所も同一場所に固定し，低温から徐々に数台の ガスストーブを用い温度を上昇させ，その過程において 行つたものである. 用いた供試虫は羽化 9 日後のもので ある。

イエバエ成虫は普通の水では，その水面に飛来しても 容易にとび去るが，約 $0.1 \%$ 以上の中性洗剤（商品名ラ イポン）であると，その水面を離れることが出来なくな b.
この性質を利用して，狭い場所にモ千等を他の面につ けずに入れることが困難なハエとり紙の代りに使用した ものである。

考え方としては，ハエとり紙を置いたのと同じである と思われる。

この結果からすると, 温度 $30^{\circ} \mathrm{C}$ 以下では, 温度の上 昇に全く比例して，その捕獲八工数も増大している.

図 17 は，この関係をグラフで図示したものである.

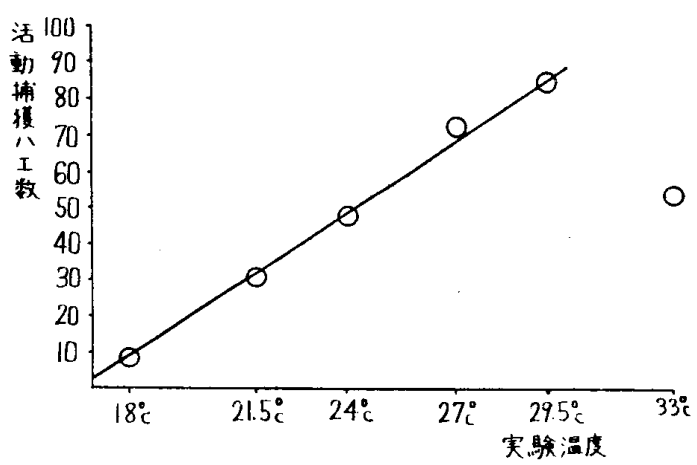

図 17 イエバェ成虫の活動数と温度との関係.

しかし，温度が $30^{\circ} \mathrm{C}$ 以上になると，おそらく，八エ が高温のため弱るためと思われるが，その捕獲数が減少 して来ている.

実験 7. 聑の喫食有無によるイエバエ成虫の活邪性の 違い: 䬺の猰食量の違いによつて，イエバエの活動性が どう変るかを検討した。

実験に供試したイエバエは，羽化 2 日後，4 日後，8 日後のものを用い，慨を供与したものを，しないものの て両者につい比較検討した。

供与した䬺は，粉末飼料（実中研，動物飼育用固型飼 料 CE-2) とふすまを同重量加え混合し, 重量にして, この飼料の 1.5 倍量の水を加え，ねつたものを 1 時間, 2 時間及び 4 時間与えたものである。なお，餌を与える 前は， $3 \%$ 砂糖水のみを充分与えた.

餌を供与しないものは，実験前は $3 \%$ の砂糖水のみ与 え, 以後 1 時閒から 4 時間, 全く餌を与えないで供試し たイエバエである。

実験した温度は $25^{\circ} \mathrm{C}$ である. 実験方法は, 実験 5 に 準する.

表 11 が，その結果であるが表中には，10 分後の捕獲 八工数のみ示した.

この結果からすると, 餌の供与時間が長くなるほど, イエバエの活動は低くなる様である．慨を与えないもの は, 2 時間後位に, 最も活動が活潑になるが，4 時間経 過すると，イエバェ自体が弱るためと思われるが，逆に 活動が低くなつて来る.

実験 2 の項において，室 $(\mathrm{H})$ に 20 個の餌を配置した 
$(80)$

表 11 イエバニ成虫の活動性，飭の喫食有無

\begin{tabular}{|c|c|c|c|c|c|}
\hline \multirow{2}{*}{\multicolumn{2}{|c|}{ 面の供与有無 }} & \multirow{2}{*}{$\mid \begin{array}{l}\text { 慨の供与 } \\
\text { 又は無供 } \\
\text { 与 時 閒 }\end{array}$} & \multicolumn{3}{|c|}{$\begin{array}{l}\text { 各羽化経過後のイエバエの } \\
\text { 10分間に捕獲された平均数 }\end{array}$} \\
\hline & & & $\begin{array}{l}\text { 羽 化 } \\
2 \text { 日後 }\end{array}$ & $\begin{array}{l}\text { 羽 化 } \\
4 \text { 日後 }\end{array}$ & $\begin{array}{l}\text { 羽 化 } \\
8 \text { 日後 }\end{array}$ \\
\hline 供 & 与 & 1 時間 & 7.5 & 45.5 & 65.0 \\
\hline 供 & 与 & $\prime \prime$ & 5.0 & 10.5 & 46.5 \\
\hline 無 & 与 & 2 時間 & 24.0 & 52.0 & 102.5 \\
\hline 供 & 与 & "l & 5.3 & 33.5 & 40.0 \\
\hline 供 & 与 & 4 時間 & 25.0 & 103.5 & 42.0 \\
\hline 供 & 与 & $\prime \prime$ & 3.5 & 26.5 & 19.5 \\
\hline
\end{tabular}

註，实験温度 $25^{\circ} \mathrm{C}$

場合，その室に設置したハエとり紙に捕獲される八エ数 が，餌を配置しないものより，はるかに少ないといら結 果が得られている。

この原因としては，䬱があるため，その所にイエバエ が集り，かつ，そこで長時間係留するためであると考え られるが，更に，ここに行つた実験の結果の様に，餌を たベることによつて，その活動がにぶくなり，その捕獲 数が減じて来るということも考えられる。

\section{考察}

八エ類, 特にイエバエに対する棲息密度を推定するた めの判定法としては，いくつかの方法がある.

その代表的なものをあげると，フライグリル，八エと り紙，八エとりリボン，布にシロップを浸み込ませ，こ れに係留した八エの数，八エとり瓶，それ江，ある所定 場所に倸留している八エ数，捕虫網等による一定回数の スィーピングなどがある.

ここにあげた幾つかの判定法について考えると，まず 所定場所に止つた八工数によるもの以外は，いずれも， イエバエが活動を起し, 各々, 判定法に用いた物体（例 えば，フライグリルの上，八エとり瓶）にまで飛来して 来なくては，観察される数はないということが注目され る.

この意味からすれば，イエバェが環境の変化によつて その係留あるい集つて来る場所が，どう変つて来るか ということと共に，どういう条件の下でより活潑に活動 移動するかといらことも重要になって来る.

ここに報告した幾つかの結果より，この点を類推する と，イエバエ成虫は一般に，温度が低、場合は，天井ま たは側面等，概して室の隅で，かつ，ある程度の高さを 持つた所に係留する．温度の上昇に併つて，室の中央に 飛来する様になり，だんだん床面に近い所に移動する。

イエバエ自体のもつ性質としては，羽化してからの日 数が少いものは，一般の八エが低温の時示す行動にやや 近く, 経過した日が多くなるにつれ，高温の時の様な行
動を示す。しかし，この差は，温度差より，かなり小さ い様である。

活動性では, 温度が $30^{\circ} \mathrm{C}$ 以下では, 温度が低くなる ほど，イエバェの活動はにぶくなる。また，特に暗い場 合にも活動しなくなる。

イエバエ自身の方から考えれば，羽化経過日数が経つ ほど，概して行動は活潑になる，但し，慨などをたべ满 腹の時は不活潑になる等があけられる。

これらの結果と，一般的にいわれている経験を基とし て判断すると, イエバエの成虫は, 動作が何んらかの理 由によつて，にぶくなつた時は，室の隅または天井の近 くに係留し, 活潑な時には, 室の中央, 床面近くに集つ て来ると考えて差支えない様である。

また，この逆も成り立つわけで，室の中央床面の近く にいる八エは，活潑に活動しているということになる。 もちろん，この性質は，その室に䬣ななど特に八エを諉 引，固定させる物質がない場合である。

これらの仮定ないしは結論から，各判定法について， その長短を検討すると，フライグリル，八エとり紙，リ ボン，瓶共に，イエバエが不活潑になる条件の時，すな わち，温度が低くなつた時，非常に暗い場合，八工の慨 となる食物が増した時には，実際，そこにいる八土数よ り低く推定し勝ちである。

一般によく問題になることであるが，雨の降つた日は イエバエが多くなる上いう人と，少なくなると言う人が ある、これは，あるい注，実際に，、ろいろの条件によ つて，その家の中にいる八エ全数が変化するのかも知れ ないが，概して，報告されたデーターが，雨の日等は少 なく，普通の住居人が多くなるといっていることは，一 方は，ある一つの観察方法によつて求められた值を信じ 他方は，文井等，目につきやすい所にいる八エを対象と: しているため上考える。

所定場所に止つている八エの数による方法は，この活 動性に対する問題は除去出来るが，各種の条件によつて その係留場所が異つて来るため，一面のみの観察では満 足であるとは結論し難い。しかし，各面，数多く観察す ること汇観察時間が多くなる等の点，問題があるう。

これに反し，捕虫網等によるスィーピング法は，人工 的にそここにいる八エを飛散させて行えば，この欠点は防 せげるが，その操作等に，個人差及び，その時の個人の 状態の相違など人為的変動が大きくなる可能性がある.

この様な事考考えれば，いずれの方法が，優れている 上は言い難いが，更に，この方面の研究の追加と合まつ て, 各々の方法が, どの様な時, どう変化するかを検討 認識した上で，適切に使用寸ることが望ましいと思う。

次に，各判定法の間の関連であるが，フライグリル， 
ハエとり紙の間には，両者共, ある一定の大きさの物体 を，平面上に置くということから，その間に大差がない ことが想像される。また八エとり瓶も，特に優れた誘引 物質を使用しない限り，同じ様な結果が求められるので はなかろうか. しかし，八エとり紙，瓶共に，その設置 時間が非常に長くなれば，フライグリルとは必ずしも一 致しないであろう。

八エとり紙とリボンは，原則として，その設置する場 所が異なるため, 理論的に一致しないと考えるのが妥当 である。

所定場所の八エ数は，非常にイエバエが活潑に活動し ている面では，ほぼ，フライグリルの結果と一致するで あろら。しかし，それ以外では異なる結果になると考え られる。

スィーピング法は，いずれも，その結果が本質的には 平行しないであろう。

少くとも, 気温, 照度, 室の構造, 餌の配置等が同じ であれば，八エの増減だけ注，どの判定法でも，明らか に区別出来ると思われるので，この様な条件が，ある一 定の範囲内に入る実験では，最も操作，労力の少ない方 法を用いればよいわけであるが，もし，薬剤散布と同時 に，室の清そう，あるいは配置変え，季節の変り目に実 験を行う場合は，より多くの面を観察する所定場所に係 留している八工数による方法が，最も安全であるう.

\section{まとめ}

室内的及び淮野外実験によつて，イエバエ成虫の駆除 効果判定法について幾つかの検討を行つた。

各種の判定法は，イエバエ成虫の各種条件によつて起 る係留場所の変化, その活動の活潑, 不活潑によつて, その結果が左右されることを確めた。

一年間に亘り, 自然の温度条件で, 一定のイエバェを 放ち，八エとり紙を用い観察した結果，温度によつて著 しく，その捕獲係留八工数が変動することを認めた.

フライグリルによる方法とハエとり紙 5 分放置による 方法の間には，本質的に，その差は認められなかつた。 また，その他の判定法についても，いくつか検討を加え た.

イエバエ成虫の異なる数を，ある一定の室に放した場 合, 放逐八工数が増大するに従つて, 各観察面に係留し たハエの数及びハエとり紙に捕獲された数も増加したが 放逐八工数と観察または捕獲八工数の間には，直線的な 比例関係は必ずしも認められなかつた。

イエバエ成虫は一般に, 温度の低い時, 満腹の時, 羽 化してからの日数が少い場合，活動がにぶくなる.

そして，活動がにぶくなつた場合は，天井，側面等，
室のすみに多く係留し, 活潑な時は, 室中央, 休面近く に多く飛来する様である。

な报，稿る終えるに当り，御指導を受けた佐々学教 授，鈴木猛博士，松永秀子氏及び室貣の皆様に厚く御礼 申し上げる。

\section{参考文献}

1）藤戸貞男 - 武衛和雄・遠藤齊萨・宅見竜雄 - 夏目 俊夫・稻葉祐一 (1959)：有機燐製郕のフィルド実験 について. 衛動， 10 (3)：197-201．－2）緒方一喜 (1960）：川崎市のある民家内にみられた八工成虫相の 季節的変化. 衛動，11（1）：17-21. -3）大利茂久・ 下鉒勝 - 福田通男 - 谷川十三生 - 大森南三郎・末永斂・ 藤崎利夫（1959）：蠅格子によるイエバェ撲滅效果の 判定法. 長崎大風土病紀要， 1(1)：60-67. -4) 鈴木 猛・椎名実 -土屋芳春・安富和男 - 喜島功・平社俊之 助 (1959)：Malathion によるハェの成虫・幼虫及び 蚊幼虫の騂除実験。衛動，10（4）：268-275，一5）平 社俊之助 (1958)： リンデン・マラシオン・ダイアジ ノ等のイエバェ成虫に対する効力の薬斉处理面の性質 による差異について。衛動, 9 (3).

\section{Summary}

Semi-field and laboratory experiments were conducted to obtain some observations concerning the evaluating methods of house fly population. The number of house flies counted by each evaluating methods such as fly grill, fly paper, fly ribbon and the others was varied by extent of activity of the house flies.

The activity, in general, increased at high temperature except at above $30^{\circ} \mathrm{C}$. When the number of activated house flies, which recorded in this test, was plotted against the temperature, a straight-line relationship was obtained in $15^{\circ} \mathrm{C}$ to $30^{\circ} \mathrm{C}$. Old age or starvation has made the flies more active. In a room test, the number of flies released in the room, vs, the number of the flies which alighted on some surface, did not generally give a straightline relationship. This was ascertained on the index of the fly grill and fly paper. These results indicated that the counts of house flies obtained from each evaluating methods were influenced by temperature, stage and feeding or starvation of the house flies.

It was generally observed in rooms that house flies, which decreased activity in some condition, would choice the resting place on the ceiling or on side of the walls. On the other hand, activated flies have alighted on the floor and concentrated in a center of the room. From this observation, house flies which alighted on the fly grill or on the fly paper placed on the floor, would increase in num- 
bers as temperature increased, and decreased at low temperatures. When various numbers of flies were releaced in a room, the index of the flies of the fly paper was essentially similar to that of the fly grill. The index of the fly grill has more fluctuated than that of the fly paper.

\section{八エ駆除のための殺虫剤実地散布試験 における効果判定法の検討}

\section{The evaluating method on the effect of control in field tests}

$\begin{array}{rcr}\text { 大 } & \text { 晃 } & \text { 治* }^{*} \\ \text { Kōji } & \text { Ôgushi }\end{array}$

\section{まえがき}

室内における種々の試験は，究極において，実際の使 用に際しての効果に適用されるという点に重点をおくべ きである. 衛生害虫の駆除が，その害虫の棲息数の抑圧 を目的とする以上，実地試験に扔ける効果判定について は，対象害虫の殺虫剤散布前後における棲息密度の増減 により推定する以外の方法は考えられない．

ところが重要な衛生害虫である，八工や蚊は繁殖能力 がきわめて高く，しかも移動性に富むため，その棲息密 度を客観的に把握することが甚だむつかしい，八エに対 して, 従来は Fly trap としてハエとり籠又は瓶，八エ とりリボン，八エとり紙及び八エ格子の方法が用いられ ている、これを殺虫剤散布による実地試験の効果判定を 目的にした場合には，簡便に行い得るといらことも重要 な条件である，小規模の実地試験においては，全家屋の 測定も可能であるが，相当な規模の実地試験においては 全家屋の測定は，困難なことであるために，実験地の代 表的な棲息密度を示すものを選定する必要があり，これ により実験のための作業を簡便にする必要がある. 主と して, 八エを対象に, 殺虫剤の実地散布試験の効果判定 について, 著者の行つた各種の実験データから検当を加 えてみた。

\section{I. 殺虫剂散布前，中，後期における栱息密度 に関する実験}

\section{実 験場所}

実験場所は福岡市大井町の全戸数の 4 戸を選定した.

* 近藤化学工業株式会社

Kondō Chem. Ind. LTD., Fukuoka Japan.
本町は板付飛行場の東北部にあつて，本町の中心に道路 があり，職業は主として農業で，小数の給料生活者を含 んでいる．本町には，4 戸の鶏舎と 25 戸の畜舎がある. 周囲は水田で，肥料溜及び浅い池がある。文付近には古 い塵芥捨場があり，肥料溜は毎日のように市内の粪尿汲 取人による貯蔵所となつている，過去における殺虫剤散 布沙く，発生源対策も何ら行われず，毎年多くの八エ になやまされている所であつた。

\section{実験期間}

本実験は三部に分けて行い，（I）イエバエ類の棲息 密度測定法. 殺虫剤散布前の棲息密度に関する実験注, 1956 年 6 月 17 日〜 7 月 18 日までの, 残留性殺虫剂散布 前の30日間を選んだ（II）殺虫剂散布後，殺虫剤の効 果, 测定期間中の棲息密度の変化に関寸る実験は引続き 8 月末日までを選んだ（III）殺虫剤効力消失後の棲息 密度に関する実験は引続き 10 月中旬まで行つた。

\section{測定方法}

測定方法はハエとりリボン (Fly ribbon)，八エとり瓶 (Fly trap) 及び八エ格子 (Fly grill) の三者によつて 行い，測定は実験地の全戸数をいずれかの測定法によつ て毎日行つた.

（1）八エとりリボンによる測定法

本町 74 户の中の $1 / 3$ の 24 力所を任意抽出した。この 中に, 4 力所渓鳥舎を選定し, その他は住居内の炊事場, または食事をする居間を選び，市販のハエとりリボンを 吊り下げ，通風の良好な所，または人の通路は除いた. リボンへの八エ付着は 1 日 24 時間で，50匹以上のもの はとり替え,この数に達しないものは数日間使用した. 